\title{
About the influence of environmental factors on the persistence of DNA — a long-term study
}

\author{
Micaela Poetsch ${ }^{1} \Subset \cdot$ Philipp Markwerth $^{1} \cdot$ Helen Konrad ${ }^{1} \cdot$ Thomas Bajanowski $^{1} \cdot$ Janine Helmus ${ }^{1}$
}

Received: 17 August 2021 / Accepted: 9 February 2022 / Published online: 23 February 2022

(c) The Author(s) 2022

\begin{abstract}
DNA persistence and DNA transfer are important features in the assessment of a crime scene. The question how long DNA may persist at a certain location is similarly important as the one how the DNA has been transferred to this location. Depending on the source of the DNA as well as the conditions at the crime scene, the answer to this question is quite difficult. In this study, persistence of DNA from epithelial abrasions, blood cells, and saliva cells in indoor and outdoor scenarios has been investigated with regard to exposure time and exposure conditions including sunlight, temperature, and humidity in summer and winter scenarios. Overall, we generated 338 epithelial samples, 572 blood samples, and 572 saliva samples. A complete profile of the cell/DNA donor after exposure could be obtained in $47 \%, 65 \%$, and $58 \%$ of epithelial abrasions, blood samples, and saliva samples, respectively. Regarding blood samples, there were no differences between supporting materials cloth and plastic; however, the percentage of complete profiles was higher for saliva samples on plastic and for epithelial samples on cloth. In indoor scenarios, complete profiles could be recovered from nearly all blood and saliva samples up to 9 months, whereas the amount of epithelial complete profiles already started to decline after 3 months. In outdoor scenarios, we observed a tipping point at an exposure time of 3 months. Blood and saliva samples collected after this period displayed complete profiles in less than $25 \%$ of samples. After 12 months, no outdoor sample showed a complete profile. The results of this study facilitate decisions on the relevance of recovered DNA from crime scenes.
\end{abstract}

Keywords Persistence of DNA · Indoor · Outdoor · Weather · Environment · Temperature $\cdot$ STR analysis $\cdot$ Low-copy number DNA

\section{Introduction}

The great progress in forensic DNA analysis has led to DNA testing being conducted regularly and on a large scale during police investigations [1], since it is now possible to create DNA profiles from even the smallest amounts of DNA secured at a crime scene [2]. However, the impact of these DNA traces has to be evaluated carefully [3-5]. Here, two main features should be considered: first, in which way has the DNA been transferred to the location or item and second, how long could the DNA have persisted at this location/on this item before sampling. Depending on the source of the DNA as well as the conditions at the crime scene, the answer to the second question is quite difficult. While several studies

Micaela Poetsch

micaela.poetsch@uk-essen.de

1 Institute of Legal Medicine, University Hospital Essen, Hufelandstr. 55, 45122 Essen, Germany deal with the possibilities of DNA transfer [e.g., 6-9], studies on the persistence of DNA are still rare and have mostly been conducted under laboratory conditions [10-13]. Investigations of outdoor scenarios are mainly limited to restricted conditions [14-19]. Especially, the influence of weather on DNA stability is a very rare topic. A recent study run in Singapore under tropical conditions showed that DNA persistence on items left outdoors showed a great variation, mostly dependent on the amount of rain [20]. Therefore, we investigated DNA samples from epithelial abrasions, blood cells, and saliva cells in indoor and outdoor scenarios under humid temperate climate conditions. 


\section{Material and methods}

\section{Samples}

The study comprised blood, saliva, and epithelial abrasions from two individuals of different age (35 years, 53 years), without any known skin disease to exclude an influence of the shedder status as described by Kamphausen et al. [21]. Samples were collected in 2019 and 2020 in the Institute of Legal Medicine, University Hospital Essen, Germany.

\section{Compliance with ethical standards}

All samples were obtained after informed consent and with approval of the Medical Ethics Committee at the University of Duisburg-Essen in accordance with the Declaration of Helsinki and national laws (ethic vote number: 09-3950, 20-9523-BO).

\section{Artificial scenarios}

Several different scenarios were set up (Table 1); in each one we used $20 \mu \mathrm{l}$ and $100 \mu \mathrm{l}$ of blood and saliva, directly pipetted on cloth and plastic, as well as neck abrasions on cloth and plastic, gained by rubbing cloth or plastic over the neck for approximately $5 \mathrm{~s}$ with medium pressure (Figure S1). Application areas for blood and saliva were marked to facilitate retrieval of cells/DNA. Exposure times started with 5 days and went up to 12 months (Table 1). For each scenario, four blood samples, four saliva samples, and two neck abrasions were analyzed. Every scenario with an exposure time of at least 2 weeks was executed twice for every material/amount. Moreover, several scenarios with exposure times of at least 1 month were carried out in summer and winter months (see Table S1 for weather conditions in summer and winter as well as definition of summer and winter for this study). After the appropriate period, cloth and plastic pieces were collected and dried in a DNA-free environment. Negative controls of cloth and plastic were investigated prior to execution of scenarios. Overall, we generated 338 epithelial samples, 572 blood samples, and 572 saliva samples.

\section{DNA extraction, quantification, amplification, and electrophoresis}

Collecting of DNA from plastic surfaces as well as cotton clothes was done as described before [22]. DNA extraction was performed using DNA IQ Casework Pro Kit and Casework Extraction Kit in the Maxwell 16® instrument according to the manufacturer's instructions (Promega, Mannheim, Germany), resulting in an extraction volume of $50 \mu \mathrm{l}$.

Table 1 Artificial scenarios

\begin{tabular}{|c|c|c|c|c|c|c|c|c|c|}
\hline \multirow[t]{2}{*}{ Time period } & \multicolumn{2}{|c|}{ Indoor, room temperature } & \multicolumn{6}{|c|}{ Outdoor, environmental temperature } & \multirow{2}{*}{$\begin{array}{l}\text { Number } \\
\text { of sam- } \\
\text { ples }\end{array}$} \\
\hline & In the dark & $\begin{array}{l}\text { Under } \\
\text { sunlight }^{1}\end{array}$ & $\begin{array}{l}\text { Dark and } \\
\text { dry, on } \\
\text { soil }\end{array}$ & $\begin{array}{l}\text { Light and } \\
\text { dry, on } \\
\text { soil }\end{array}$ & $\begin{array}{l}\text { Light and } \\
\text { exposed, on } \\
\text { soil }\end{array}$ & $\begin{array}{l}\text { Dark and dry, } \\
\text { on polystyrene }\end{array}$ & $\begin{array}{l}\text { Light and dry, } \\
\text { on polystyrene }\end{array}$ & $\begin{array}{l}\text { Light and } \\
\text { exposed, on } \\
\text { cloth }\end{array}$ & \\
\hline 5 days $^{4} ; \mathrm{s}$ & $\mathrm{x}$ & $\mathrm{x}$ & $\mathrm{x}$ & $\mathrm{x}$ & $\mathrm{x}$ & $\mathrm{x}$ & $\mathrm{x}$ & $\mathrm{x}$ & 82 \\
\hline 1 week $^{3} ; \mathrm{s}$ & $\mathrm{x}$ & $\mathrm{x}$ & $\mathrm{x}$ & $\mathrm{x}$ & $\mathrm{x}$ & $\mathrm{x}$ & $\mathrm{x}$ & $\mathrm{x}$ & 80 \\
\hline 2 weeks ${ }^{2} ; \mathrm{s}$ & $\mathrm{x}$ & $\mathrm{x}$ & $\mathrm{x}$ & $\mathrm{x}$ & $\mathrm{x}$ & $\mathrm{x}$ & $\mathrm{x}$ & $\mathrm{x}$ & 160 \\
\hline 3 weeks ${ }^{2} ; \mathrm{s}$ & & & $\mathrm{x}$ & $\mathrm{x}$ & $\mathrm{x}$ & & & & 120 \\
\hline 1 month $^{2} ; \mathrm{s}, \mathrm{w}$ & $\mathrm{x}$ & $\mathrm{x}$ & $\mathrm{x}$ & $\mathrm{x}$ & $\mathrm{X}$ & $\mathrm{x}$ & $\mathrm{x}$ & $\mathrm{x}$ & 320 \\
\hline $\begin{array}{l}3 \text { months }^{2} \\
\text { s, w }\end{array}$ & $\mathrm{x}$ & $\mathrm{x}$ & $\mathrm{x}$ & $\mathrm{x}$ & $\mathrm{x}$ & $\mathrm{x}$ & $\mathrm{x}$ & $\mathrm{x}$ & 320 \\
\hline $\begin{array}{l}6 \text { months }^{2} ; \\
\text { s, w }\end{array}$ & $\mathrm{x}$ & $\mathrm{x}$ & $\mathrm{x}$ & & & $\mathrm{x}$ & $\mathrm{x}$ & & 200 \\
\hline 9 months $^{2}$ & $\mathrm{x}$ & $\mathrm{x}$ & $\mathrm{x}$ & & & $\mathrm{x}$ & $x$ & & 100 \\
\hline 12 months $^{2}$ & $\mathrm{x}$ & $\mathrm{x}$ & $\mathrm{x}$ & & & $\mathrm{x}$ & $\mathrm{x}$ & & 100 \\
\hline
\end{tabular}

$x$ scenario was executed, $s$ summer months, $w$ winter months (see Table $\mathrm{S} 1$ for definition).

${ }^{1}$ Samples were stored on a windowsill facing southwest to increase the amount of sunlight as much as possible.

${ }^{2}$ For each of these scenarios, four blood samples $(20 \mu \mathrm{l}$ and $100 \mu \mathrm{l}$, on cloth and plastic), four saliva samples $(20 \mu \mathrm{l}$ and $100 \mu \mathrm{l}$, on cloth and plastic), and two neck abrasions (on cloth and plastic) were analyzed. Every scenario was executed twice.

${ }^{3}$ For these scenarios, four blood samples $(20 \mu \mathrm{l}$ and $100 \mu \mathrm{l}$, on cloth and plastic), four saliva samples (20 $\mu \mathrm{l}$ and $100 \mu \mathrm{l}$, on cloth and plastic), and two neck abrasions (on cloth and plastic) were analyzed without repetition.

${ }^{4}$ For these scenarios, four blood samples $(20 \mu \mathrm{l}$ and $100 \mu \mathrm{l}$, on cloth and plastic), four saliva samples (20 $\mu \mathrm{l}$ and $100 \mu \mathrm{l}$, on cloth and plastic), and two neck abrasions (on cloth and plastic) were analyzed. A repetition war only executed for neck abrasions under the conditions, "light and exposed, on cloth". 
DNA concentration of samples was established by Real-time PCR using the PowerQuant ${ }^{\mathrm{TM}}$ System (Promega) according to the manufacturer's instructions providing a reproducible and reliable detection threshold at least down to $25 \mathrm{pg}$ DNA [23]. Using $2 \mu \mathrm{l}$ DNA-containing solutions each sample was analyzed in duplicates. DNA amplification with multiplex PCR Kit Powerplex® ESX17fast, evaluation on an ABI3500 Genetic Analyzer (Applied Biosystems) with GeneMapper ${ }^{\circledR}$ ID-X Software, and assessment of results regarding complete profiles were done as described before [9]. In short, a result was regarded as a complete profile, if in every evaluable locus every allele of the cell donor was found.

\section{Results and discussion}

\section{Reliability of data and DNA concentrations}

All negative controls showed no profiles; DNA amount was either negative (undetermined according to PowerQuant System) or below $0.0005 \mathrm{ng} / \mu \mathrm{l}$.

First, we established expected DNA yields for our samples by analyzing 16 different samples for each chosen amount of blood and saliva as well neck abrasions (Table S2). Here, $20 \mu \mathrm{l}$ and $100 \mu \mathrm{l}$ blood resulted in 152-928 ng DNA (mean $465 \mathrm{ng}$ ) and 693-3898 ng DNA (mean $1438 \mathrm{ng}$ ), respectively. DNA yield of saliva samples was slightly lower, since $20 \mu \mathrm{l}$ and $100 \mu \mathrm{l}$ saliva contained 190-667 ng DNA (mean $381 \mathrm{ng}$ ) and 262-1617 ng DNA (mean $735 \mathrm{ng}$ ), respectively. As expected, recovery of DNA from neck abrasions was less successful with 17.7-44.5 ng (mean $28 \mathrm{ng}$ ), but still sufficient to create a complete profile of the donor.

DNA concentrations of samples from the different scenarios measured by Real-time PCR varied widely between the different experimental setups as well as different cell origins (Table S3), but corresponded to the results of the STR analysis (samples with a DNA concentration below $0.0005 \mathrm{ng} /$ $\mu \mathrm{l}$ demonstrated no profiles). As expected, DNA concentrations of samples from experiments with saliva or blood were higher than regarding experiments with skin cells. Loss of DNA over exposure time occurred in different amounts between different scenarios. After 3 months indoors, nearly $80 \%$ and $70 \%$ of DNA from blood and saliva were lost, respectively (Table S3). Similar values could be obtained in outdoor scenarios with a mean loss of $92 \%$ (blood) and $97 \%$ (saliva), although with a greater range (0-47\% and 0-9\% recovery rate for blood and saliva, respectively). Regarding epithelial abrasions, DNA amount after 1 month varied between $1.7 \mathrm{ng}$ and $25.3 \mathrm{ng}$ in the indoor scenarios, whereas 0-11.5 ng DNA could be found in epithelial abrasions regarding outdoor scenarios. These values are lower than those reported by Lee et al. [20] with 28-137 ng DNA in keratinocyte suspensions in indoor scenario after 4 weeks, but higher than those detected on wristbands $(0-0.39 \mathrm{ng})$ [20], the last setup being much more comparable to our scenarios. After 12 months, we lost $100 \%$ of DNA in nearly every outdoor scenario, which is in line with the results from Lee et al. [20].

\section{STR amplification}

Looking at the results with no regard to the scenario, complete profiles could be demonstrated in 861 samples (58\% of all samples). Only 177 samples (12\%) showed a partial profile, distributed equally about different scenarios and cell origins. Since the amount of partial profiles in this study is rather low, we decided to concentrate on complete profiles only for all further evaluations. Moreover, although a partial profile may sometimes provide information for a possible assignment of a person to a DNA samples, it does not offer enough certainty to allow a biostatistical calculation in Germany $[24,25]$.

\section{Relevance of cell origin}

Considering cellular origin, 373 blood samples (65\% of blood samples), 330 saliva samples (58\% of saliva samples), and 158 epithelial samples (47\% of epithelial samples) showed a complete profile (Table 2). These differences were not surprising, since fresh blood contains about 4000-10,000 leukocytes/ $\mu$ [26], while other studies have shown that saliva samples can be expected to contain about

Table 2 Distribution of the amount of complete profiles with regard to cell origin and supporting material

\begin{tabular}{|c|c|c|c|}
\hline & Blood samples $(n=572)^{*}$ & Saliva samples $(n=572)^{*}$ & Epithelial samples $(n=338)^{*}$ \\
\hline Complete profiles & $373(65 \%)$ & $330(58 \%)$ & $158(47 \%)$ \\
\hline Complete profiles on plastic & 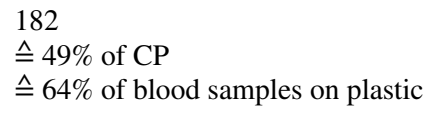 & 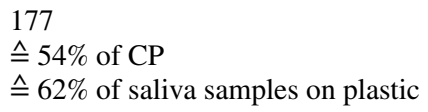 & $\begin{array}{l}69 \\
\triangleq \\
\stackrel{=}{=} 44 \% \text { of } \mathrm{CP} \\
41 \% \text { of epithelial samples on plastic }\end{array}$ \\
\hline Complete profiles on cloth & $\begin{array}{l}191 \\
\triangleq 51 \% \text { of } \mathrm{CP} \\
\triangleq \quad 67 \% \text { of blood samples on cloth }\end{array}$ & $\begin{array}{l}153 \\
\bumpeq 46 \% \text { of } \mathrm{CP} \\
\triangleq 53 \% \text { of saliva samples on cloth }\end{array}$ & $\begin{array}{l}89 \\
\stackrel{\wedge}{=} 56 \% \text { of } \mathrm{CP} \\
\triangleq 53 \% \text { of epithelial samples on cloth }\end{array}$ \\
\hline
\end{tabular}

*Half of samples were on plastic, half on cloth. 
3000 cells/ml, with highly variable composition [27, 28]. Regarding epithelial samples, it is known that the majority of the cells are nuclei-free [29].

A higher resilience of saliva samples has already been demonstrated [22] and may be due to cell composition (salivary cells, inflammatory cells) or the presence of glycoproteins [30] which enhance the adhesion of cells and DNA to the surface [31].

\section{Influence of supporting material}

There were no differences in the number of complete profiles between samples on plastic and samples on cloth (428 and 433 complete profiles, respectively). However, the results did vary, if the origin of the cells was also considered (Table 2). On cloth, epithelial samples are more prone to conserve enough DNA for a complete profile than on plastic, a phenomenon which has been described before [31, 32]. Moreover, epithelial cells detach more easily from smooth surfaces and got lost as shown by Goray et al. [33]. In contrast, it is more probable to detect a complete profile from saliva samples on plastic than on cloth, which again may be due to the presence of glycoproteins that enhance the adhesion of cells and DNA to the surface [30].

\section{Indoor scenarios}

For an exposure period of up to 9 months, nearly all blood and saliva samples stored in the dark resulted in complete profiles as expected (Fig. 1), since especially blood samples collected on paper or cloth are routinely stored for much longer time frames. Rather surprisingly, only $50 \%$ of blood samples and $75 \%$ of saliva samples demonstrated all alleles of the responsible individual after an exposure of 12 months. This can possibly be explained by the use of plastic as supporting material as well as the rather low amount of $20 \mu \mathrm{l}$ blood in some samples, since these samples showed the most allele losses. Moreover, we often observed a flaking of blood samples thus reducing the amount further. Regarding epithelial abrasions, the results are quite different (Fig. 1). After 3 months, only half of samples demonstrated a complete profile, after 12 months none, not even those in the dark. Here, not UV radiation as expected but another factor seems to be relevant. Possibly the different composition of the bacterial fauna on the skin compared to, for example, the bacterial fauna in saliva could have an influence [34].

The influence of sunlight was investigated in the second indoor scenario. Blood and saliva samples showed a high amount of complete profiles up to 9 months of storage (Fig. 1); however, only $13 \%$ of saliva samples demonstrated all expected alleles after 12 months. In blood samples, we found complete profiles in 50\% of samples, same as in the dark scenario. Generally, the destructive effects of UV
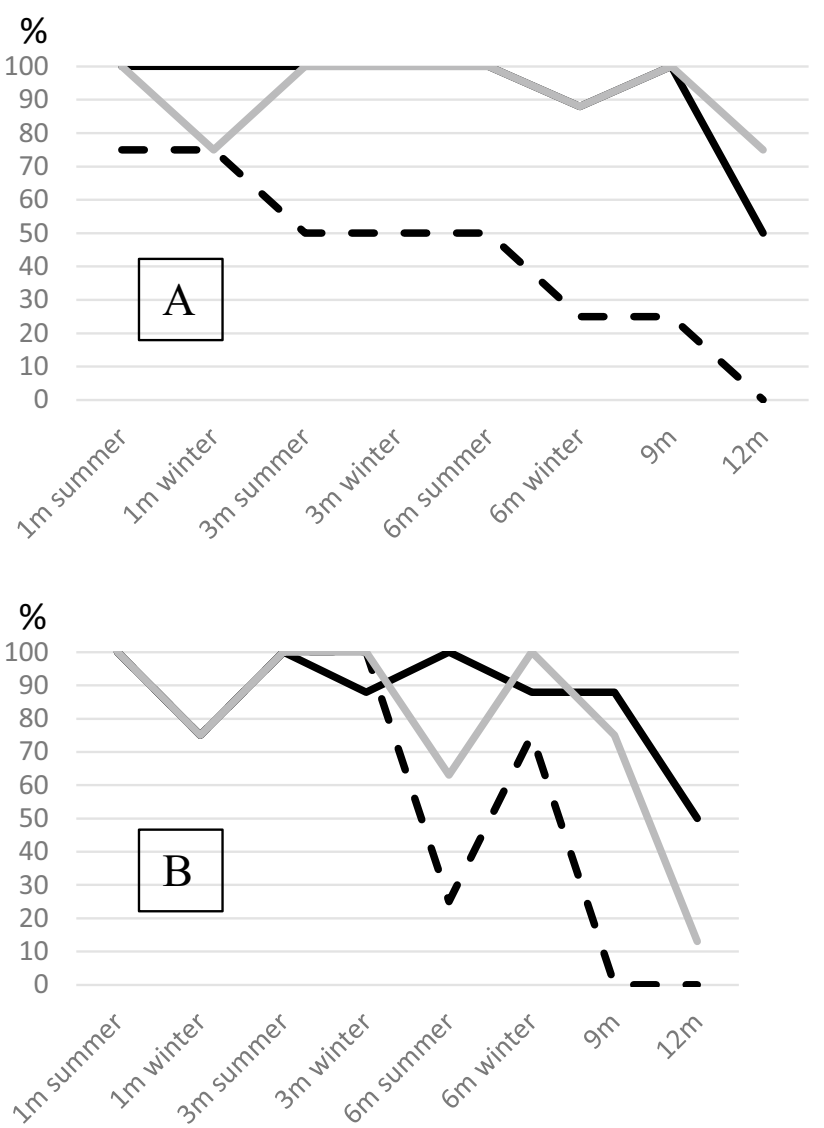

Fig. 1 Graphical display of the percentage of samples with complete profile with regard to the different indoor scenarios and exposure time (starting with 1 month). A In the dark and $\mathbf{B}$ under sunlight. Black lines represent blood samples, grey lines represent saliva samples, and interrupted lines stand for epithelial samples

radiation on DNA are well known and used for removal of DNA from instruments and surfaces [35]. However, terrestrial UV light alone has already been shown to be an only minor contributor to DNA damage [36] as confirmed by the results of this study.

\section{Outdoor scenarios}

The outdoor scenarios were divided in two main sections: the storage was done either on soil or on polystyrene/cloth to get some insights in the influence of chemical components of the soil as well as bacteria or small animals as insects or worms.

Not surprisingly, the portion of complete profiles in general was lower in outdoor than in indoor scenarios (Fig. 2). Especially on soil, an exposure time of 3 months proved to be a tipping point; after that, only few complete profiles could be found in blood and saliva samples (Fig. 2). This tipping point seems also be true for the unprotected blood and saliva samples on cloth (Fig. 2). Epithelial abrasions 
Fig. 2 Graphical display of the percentage of samples with complete profiles with regard to the different outdoor scenarios and exposure times (starting with 1 week). A Dark and dry on soil, $\mathbf{B}$ light and dry on soil, $\mathbf{C}$ light and exposed on soil, $\mathbf{D}$ dark and dry on polystyrene, E light and dry on polystyrene, and $\mathbf{F}$ light and exposed on cloth. Black lines represent blood samples, grey lines represent saliva samples, and interrupted lines stand for epithelial samples
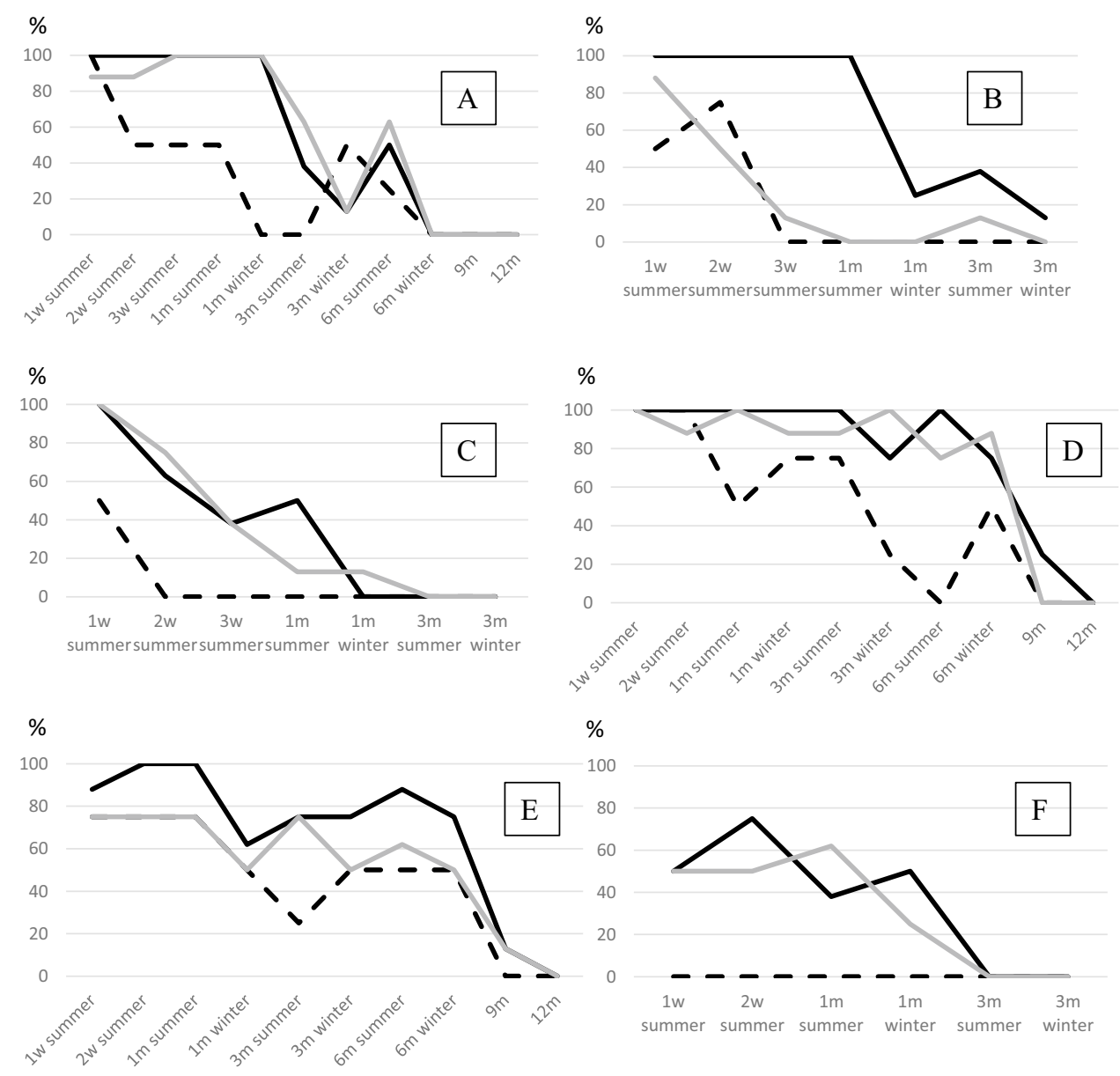

rendered no results as early as after 2 weeks (Fig. 2C, completely exposed), 3 weeks (Fig. 2B, with light), or 1 month (Fig. 2A, in the dark). In contrast, on polystyrene, complete profiles could be demonstrated for as long as 9 months in individual blood and saliva samples and as long as 6 months in epithelial abrasions (Fig. 2). While Lee et al. found a significant influence of the growth of fungus on the prevalence of DNA in the outdoor scenarios [20], direct contact with the bacterial flora of the soil seems to be the main influencing factor here. This is in line with another study investigating the stability of DNA in direct contact with soil [37]. A direct correlation between growth of fungus/bacteria with resulting loss of DNA to the amount of rainfall during the study period as described by Lee et al. [20] could not be observed in this study. This may be due to the difference in climate as well as regarding the amount of rainfall which is much lower in this study than in Singapore.

In general, samples from the summer scenarios demonstrated more complete profiles than those of winter scenarios, regardless of the source of DNA (Table S4). While $52 \%$ of all summer samples showed a complete profile, only $37 \%$ of winter samples had this result. The most striking differences could be found in blood samples, since in $61 \%$ of summer samples but only in $38 \%$ of winter samples all alleles of the responsible person were detected. Therefore, the influence of lower temperatures and - especially a higher humidity seems to outrank that of sunlight. The influence of humidity on DNA persistence has already been discussed in several studies [19, 38, 39], whereby in this study especially milder temperatures and high humidity may have favored microbial colonization. Another study has also described this phenomenon [40]. Moreover, the much greater loss of DNA from any source on soil than on polystyrene also favors this explanation. In this context, it should be noted that in 2019 the summer was relatively dry.

\section{Conclusion}

The results of this study demonstrate a rather distinctive time frame for a possible recovery of DNA from blood, saliva, and epithelial cells after exposure to sun and rain as well as high and low temperatures. This information could be helpful during police investigation and in court to evaluate the chances of successful DNA typing and to facilitate decisions on the relevance of recovered DNA from crime scenes. 
Supplementary Information The online version contains supplementary material available at https://doi.org/10.1007/s00414-022-02800-6.

Funding Open Access funding enabled and organized by Projekt DEAL.

\section{Declarations}

Ethics approval All samples were obtained after informed consent and with approval of the Medical Ethics Committee at the University of Duisburg-Essen in accordance with the Declaration of Helsinki and national laws (ethic vote number: 09-3950, 20-9523-BO).

Conflict of interest The authors declare no competing interests.

Open Access This article is licensed under a Creative Commons Attribution 4.0 International License, which permits use, sharing, adaptation, distribution and reproduction in any medium or format, as long as you give appropriate credit to the original author(s) and the source, provide a link to the Creative Commons licence, and indicate if changes were made. The images or other third party material in this article are included in the article's Creative Commons licence, unless indicated otherwise in a credit line to the material. If material is not included in the article's Creative Commons licence and your intended use is not permitted by statutory regulation or exceeds the permitted use, you will need to obtain permission directly from the copyright holder. To view a copy of this licence, visit http://creativecommons.org/licenses/by/4.0/.

\section{References}

1. Prahlow JA, Cameron T, Arendt A, Cornelis K, Bontrager A, Suth MS, Black L, Tobey R, Pollock S, Stur S, Cotter K, Gabrielse J (2017) DNA testing in homicide investigations. Med Sci Law 57:179-191

2. Thompson R, Zoppis S, McCord B (2012) An overview of DNA typing methods for human identification: past, present, and future. Methods Mol Biol 830:3-16

3. Inman K, Rudin N (2002) The origin of evidence. Forensic Sci Int 126:11-16

4. Raymond JJ, Walsh SJ, van Oorschot RAH, Gunn PR, Roux C (2004) Trace DNA: an underutilized resource or Pandora's box? A review of the use of trace DNA analysis in the investigation of volume crime, Journal of Forensic Identification 54:668-686

5. van Oorschot RAH, Szkuta B, Meakin GE, Kokshoorn B, Goray M (2019) DNA transfer in forensic science: a review. Forensic Sci Int Genet 38:140-166

6. Phipps M, Petricevic S (2007) The tendency of individuals to transfer DNA to handled items. Forensic Sci Int 168:162-168

7. van Oorschot RA, Glavich G, Mitchell RJ (2014) Persistence of DNA deposited by the original user on objects after subsequent use by a second person. Forensic Sci Int Genet 8:219-225

8. Goray M, van Oorschot RAH (2015) The complexities of DNA transfer during a social setting. Leg Med 17:82-91

9. Helmus J, Bajanowski T, Poetsch M (2016) DNA transfer - a never ending story. A study on scenarios involving a second person as carrier. Int J Legal Med 130:121-125

10. Raymond JJ, Walsh SJ, van Oorschot RA, Gunn PR, Evans L, Roux C (2008) Assessing trace DNA evidence from a residential burglary: abundance, transfer and persistence. Forensic Science International: Genetics Supplement Series 1:442-443

11. Poetsch M, Pfeifer M, Konrad H, Bajanowski T, Helmus J (2017) Impact of several wearers on the persistence of DNA on clothes - a study with experimental scenarios. Int J Legal Med 132:117-123

12. Szkuta B, Ballantyne KN, van Oorschot RAH (2017) Transfer and persistence of DNA on the hands and the influence of activities performed. Forensic Sci Int Genet 28:10-20

13. Szkuta B, Ansell R, Boiso L, Connolly E, Kloosterman AD, Kokshoorn B, McKenna LG, Steensma K, van Oorschot RAH (2019) Assessment of the transfer, persistence, prevalence and recovery of DNA traces from clothing: an inter-laboratory study on worn upper garments. Forensic Sci Int Genet 42:56-68

14. Raymond JJ, van Oorschot RA, Gunn PR, Walsh SJ, Roux C (2009) Trace evidence characteristics of DNA: a preliminary investigation of the persistence of DNA at crime scenes. Forensic Sci Int Genet 4:26-33

15. Steensma K, Ansell R, Clarisse L, Connolly E, Kloosterman AD, McKenna LG, van Oorschot RAH, Szkuta B, Kokshoorn B (2017) An inter-laboratory comparison study on transfer, persistence and recovery of DNA from cable ties. Forensic Sci Int Genet 31:95-104

16. Pfeifer CM, Gass A, Klein-Unseld R, Wiegand P (2017) DNA persistence of bite marks on food and its relevance for STR typing. Int J Legal Med 131:1221-1228

17. Emmons AL, DeBruyn JM, Mundorff AZ, Cobaugh KL, Cabana GS (2017) The persistence of human DNA in soil following surface decomposition. Sci Justice 57:341-348

18. Mcleish K, Ferguson S, Gannicliffe C, Campbell S, Thomson PIT, Webster LMI (2018) Profiling in wildlife crime: recovery of human DNA deposited outside. Forensic Sci Int Genet 35:65-69

19. Helmus J, Zorell S, Bajanowski T, Poetsch M (2018) Persistence of DNA on clothes after exposure to water for different time periods - a study on bathtub, pond and river. Int J Legal Med 132:99-106

20. Lee LYC, Wong HY, Lee JY, Waffa ZBM, Aw ZQ, Fauzi SNABM, Hoe SY, Lim ML, Syn CK (2019) Persistence of DNA in the Singapore context. Int J Legal Med 133:1341-1349

21. Kamphausen T, Schadendorf D, von Wurmb-Schwark N, Bajanowski T, Poetsch M (2012) Good shedder or bad shedderthe influence of skin diseases on forensic DNA analysis from epithelial abrasions. Int J Legal Med 126:179-183

22. Helmus J, Poetsch J, Pfeifer M, Bajanowski T, Poetsch M (2019) Cleaning a crime scene 2.0 - what to do with the bloody knife after the crime? Int J Legal Med 134:171-175

23. Poetsch M, Konrad H, Helmus J, Bajanowski T, von WurmbSchwark N (2016) Does zero really mean nothing?-first experiences with the new PowerQuant(TM) system in comparison to established real-time quantification kits. Int J Legal Med 130:935-940

24. Schneider PM, Fimmers R, Keil W, Molsberger G, Patzelt D, Pflug W, Rothämel T, Schmitter H, Schneider H, Brinkmann B (2006) Allgemeine Empfehlungen der Spurenkommission zur Bewertung von DNA-Mischspuren. Rechtsmedizin 16:401-404

25. Ulbrich W, Anslinger K, Bäßler G, Eckert M, Fimmers R, Hohoff C, Kraft M, Leuker C, Molsberger G, Pich U, Razbin S, Schneider H, Templin M, Wächter A, Weirich V, Zierdt H, Schneider PM (2016) Gemeinsame Empfehlungen der Projektgruppe „Biostatistische DNA-Berechnungen“ und der Spurenkommission zur biostatistischen Bewertung von DNA-analytischen Befunden. Rechtsmedizin 26:291-298

26. Nebe T, Bentzien F, Bruegel M, Fiedler G, Gutensohn K, Heimpel H, Krebs N, Ossendorf M, Schuff-Werner P, Stamminger G, Baum H (2011) Multizentrische Ermittlung von Referenzbereichen für Parameter des maschinellen Blutbildes/Multicentric Determination of Reference Ranges for Automated Blood Counts. LaboratoriumsMedizin 35:3-28 
27. Simpson JL, Timmins NL, Fakes K, Talbot PI, Gibson PG (2004) Effect of saliva contamination on induced sputum cell counts, IL-8 and eosinophil cationic protein levels. Eur Respir J 23:759-762

28. Theda C, Hwang SH, Czajko A (2018) Quantitation of the cellular content of saliva and buccal swab samples. Sci Rep 8:6944

29. Alessandrini F, Cecati M, Pesaresi M, Turchi C, Carle F, Tagliabracci A (2003) Fingerprints as evidence for a genetic profile: morphological study on fingerprints and analysis of exogenous and individual factors affecting DNA typing. J Forensic Sci 48:586-592

30. Schenkels LC, Veerman EC, Nieuw Amerongen AV (1995) Biochemical composition of human saliva in relation to other mucosal fluids. Crit Rev Oral Biol Med 6:161-175

31. Helmus J, Pfeifer M, Feiner LK, Krause LJ, Bajanowski T, Poetsch M (2019) Unintentional effects of cleaning a crime scene-when the sponge becomes an accomplice in DNA transfer. Int J Legal Med 133:759-765

32. Verdon TJ, Mitchell RJ, van Oorschot RA (2013) The influence of substrate on DNA transfer and extraction efficiency. Forensic Sci Int Genet 7:167-175

33. Goray M, Mitchell RJ, van Oorschot RAH (2010) Investigation of secondary DNA transfer of skin cells under controlled test conditions. Leg Med 12:117-120

34. Cho HW, Eom YB (2021) Forensic analysis of human microbiome in skin and body fluids based on geographic location. Front Cell Infect Microbiol 11:695191
35. Gefrides LA, Powell MC, Donley MA, Kahn R (2010) UV irradiation and autoclave treatment for elimination of contaminating DNA from laboratory consumables. Forensic Sci Int Genet 4:89-94

36. Hall A, Sims LM, Ballantyne J (2014) Assessment of DNA damage induced by terrestrial UV irradiation of dried bloodstains: forensic implications. Forensic Sci Int Genet 8:24-32

37. Badu-Boateng A, Twumasi P, Salifu SP, Afrifah KA (2018) A comparative study of different laboratory storage conditions for enhanced DNA analysis of crime scene soil-blood mixed sample. Forensic Sci Int 292:97-109

38. Kamphausen T, Fandel SB, Gutmann JS, Bajanowski T, Poetsch M (2015) Everything clean? Transfer of DNA traces between textiles in the washtub. Int J Legal Med 129:709-714

39. Voskoboinik L, Amiel M, Reshef A, Gafny R, Barash M (2018) Laundry in a washing machine as a mediator of secondary and tertiary DNA transfer. Int J Legal Med 132:373-378

40. Dash HR, Das S (2018) Microbial degradation of forensic samples of biological origin: potential threat to human DNA typing. Mol Biotechnol 60:141-153

Publisher's Note Springer Nature remains neutral with regard to jurisdictional claims in published maps and institutional affiliations. 